\title{
Two single nucleotide polymorphisms within bovine butyrophilin gene (BTN/Haelll and BTN/Schl) and their association with milk performance traits in Jersey cattle
}

\author{
MAGDALENA MUSZYŃSKA', IWONA SZATKOWSKA', WILHELM GRZESIAK², ANDRZEJ \\ DYBUS'1 and DANIEL ZABORSKI ${ }^{2}$
}

'Laboratory of Molecular Cytogenetics, '2Laboratory of Biostatistics; Department of Ruminant Sciences; Faculty of Biotechnology and Animal Breeding, West Pomeranian University of Technology, Szczecin, Poland

\begin{abstract}
Associations between two polymorphisms localized in the seventh exon of the butyrophilin gene (BTN/Haelll and BTN/Schl) and milk production traits of Jersey cattle were analysed. A total of 171 cows were included in the study. PCR-RFLP method was used. In both polymorphisms three genotypes were identified. Statistically significant differences between polymorphic variants and milk production traits of Jersey cows were observed. Those differences concerned the percentage fat content in milk in the case of both polymorphisms and additionally the yield of milk and protein in the case of BTN/Haelll polymorphism. The influence of the combined genotypes (BTN/HaellI/Schl) on the examined traits was also analysed. GGHelll/ $A G^{\text {schl }}$ combined genotype was characterized by a significantly lower percentage fat content in comparison to other combinations. Moreover, incomplete linkage between the studied polymorphic sites was observed, despite relatively small distance between them.
\end{abstract}

Keywords: butyrophilin gene, PCR-RFLP, dairy cattle, milk production traits, Jersey

\section{Zusammenfassung}

Zwei einzelne Nukleotidpolymorphismen innerhalb des Butyrophilin-Gens (BTN/Haelll und BTN/Schl) und ihr Zusammenhang mit den Milchproduktionsmerkmalen der Jersey-Rinder

Zusammenhänge zwischen den im siebten Exon des Butyrophilin-Gens lokalisierten Polymorphismen (BTN/Haelll und BTN/Schl) und den Milchleistungsmerkmalen von JerseyRindern wurden analysiert. Die Untersuchungen umfassten 171 Kühe. Es wurde die PCR-RFLPMethode angewandt. Signifikante Unterschiede zwischen den BTN/Haelll- und BTN/SchlPolymorphismen und den Milchleistungsmerkmalen wurden festgestellt. Diese Unterschiede betreffen den prozentualen Fettgehalt bei beiden Polymorphismen, die Milchleistung sowie den Eiweißgehalt im Falle des Polymorphismus BTN/Haelll. Die Polymorphismen wurden im System der kombinierten Genotypen analysiert. Der kombinierte Genotyp $G G^{\text {Heell }} / A G^{\text {schl }}$ war charakterisiert durch einen signifikant niedrigeren Prozentgehalt an Fett im Vergleich zu anderen Kombinationen. Zusätzlich wurde keine Konjugation zwischen den analysierten Polymorphismen gefunden, obwohl eine relativ kurze Entfernung zwischen beiden Polymorphismen besteht. 
Schlüsselwörter: Butyrophilin-Gen, PCR-RFLP, Milchrind, Milchproduktionsmerkmale, Jersey-Rind

\section{Introduction}

The butyrophilin protein was identified as a main component of the milk fat globule membrane (MFGM), which is important in secreting and stabilizing of milk-fat droplets in milk (FRANKE et al. 1981). Its existence was discovered and characterized in milk of many species, including human. Butyrophilin comprises $34-43 \%$ of the total MFGM proteins in the milk of Holstein-friesian cows and approximately $20 \%$ in the milk of Jersey cows (MATHER 2000). Bovine butyrophilin consists of 526 amino acids $(\sim 56 \mathrm{kDa})$, and the first 26 of them constitute a signal peptide (JACK and MATHER 1990). Butyrophilin protein exhibits a domain character of build and is a type I transmembrane glycoprotein (BANGHART et al. 1998) strongly connected with the cell membrane (JACK and MATHER 1990, MATHER and JACK 1993).

The function that butyrophilin plays in a living organism remains unknown. Taking into consideration that butyrophilin expression is strictly limited only to the apical surfaces of epithelial secretory cells of mammary gland and its presence in structures surrounding milkfat droplets in milk, it seems that butyrophilin protein is essential for the proper course of fat secretion process into milk. What is characteristic, butyrophilin is highly expressed only during the lactation and last period of pregnancy (FRANKE et al. 1981, MATHER and JACK 1993).

The bovine butyrophilin gene (BTN) was mapped to the long arm of chromosome 23 [23q21-q23] (BRUNNER et al. 1996, TAYLOR et al. 1996). It comprises seven exons and six introns (DAVEY et al. 1997). The gene structure organization corresponds to the distribution of functional domains of coding protein (DAVEY et al. 1997, OGG et al. 2004). Additionally, 5'UTR and 3'UTR are present in the butyrophilin gene structure. In 5'UTR region a short intronic sequence was found, which shows that, in the case of bovine butyrophilin gene, this region is coded by two separate exons (KOMISAREK and DORYNEK 2002, SEYFERT and LUTHEN 1998), opposed to other species, in which 5'UTR is continuous (SEYFERT and LUTHEN 1998). The butyrophilin gene promoter is an example of TATA-less promoters. In silico analysis of the bovine butyrophilin promoter region showed a number of potential transcription factor binding sites (DAVEY et al. 1997). Butrophilin gene expression is strictly regulated at the transcription level by lactogenic hormones (BANGHART et al. 1998).

Within the bovine butyrophilin gene, a number of polymorphic sites were identified, both in coding (exons) and noncoding (introns) regions (HUSAINI et al. 1999, SEYFERT and LUTHEN 1998, TAYLOR et al. 1996, ZEGEYE et al. 1999). A list of all discovered polymorphic sites, together with their location and possible influence on amino acid sequence, is showed in Table 1. Due to the function of the protein itself and the localization of the butyrophilin gene in the close neighborhood of the genes associated with the major histocompatibility complex (MHC) and several potential markers connected with production traits (ASHWELL et al. 1999), the butyrophilin gene was initially classified to the group of QTL candidate genes. The attempt to characterize the influence of particular polymorphic variants of this gene on production traits i.e. content of individual milk-components in milk (KOMISAREK and DORYNEK 2002, KOMISAREK et al. 2006b) or somatic cell count (KOMISAREK et al. 2006a) was made. 
The aim of the study was to determine the frequency of occurrence of particular genotypes and allels of BTN gene (polymorphic sites in positions 6804 and 6845) and to analyze of the relationship between examined polymorphic variants and milk performance traits in Jersey cows.

Table 1

Summary of a point mutations within the bovine butyrophilin (bBTN) gene Zusammensetzung der Punktmutationen innerhalb der Butyrofilingene (BTN)

\begin{tabular}{|c|c|c|c|c|c|}
\hline & $\begin{array}{l}\text { Nucleotide } \\
\text { position* }\end{array}$ & $\begin{array}{l}\text { Localisation } \\
\text { of mutation }\end{array}$ & $\begin{array}{l}\text { Type of } \\
\text { mutation }\end{array}$ & $\begin{array}{l}\text { Influence on amino } \\
\text { acid sequence }\end{array}$ & Reference \\
\hline 1. & 243 & 5'UTR & $\mathrm{T} \rightarrow \mathrm{C}$ & - & (HUSAINI et al. 1999) \\
\hline 2. & 1849 & Exon 1 & $\mathrm{~T} \rightarrow \mathrm{A}$ & Phe $\rightarrow$ Tyr & (HUSAINI et al. 1999) \\
\hline 3. & 1939 & Intron A & $A \rightarrow C$ & - & (ZEGEYE et al. 1999) \\
\hline 4. & 2074 & Intron A & $A \rightarrow T$ & - & (ZEGEYE et al. 1999) \\
\hline 5. & 2076 & Intron A & $A \rightarrow G$ & - & (ZEGEYE et al. 1999) \\
\hline 6. & 2281 & Exon 2 & $C \rightarrow A$ & Pro $\rightarrow$ Gln & (SEYFERT and LUTHEN, 1998) \\
\hline 7. & 3645 & Intron B & $\mathrm{G} \rightarrow \mathrm{T}$ & - & (HUSAINI et al. 1999) \\
\hline 8. & 3713 & Intron B & $\mathrm{G} \rightarrow \mathrm{A}$ & - & (HUSAINI et al. 1999) \\
\hline 9. & 4226 & Exon 3 & $A \rightarrow T$ & Glu $\rightarrow$ Asp & (HUSAINI et al. 1999) \\
\hline 10. & 5495 & Intron D & $\mathrm{G} \rightarrow \mathrm{A}$ & - & (ZEGEYE et al. 1999) \\
\hline 11. & 6658 & Exon 7 & $C \rightarrow G$ & Missens & (HUSAINI et al. 1999) \\
\hline 12. & 6673 & Exon 7 & $C \rightarrow T$ & Missens & (HUSAINI et al. 1999) \\
\hline 13. & 6804 & Exon 7 & $A \rightarrow G$ & Lys $\rightarrow$ Arg & (TAYLOR et al. 1996) \\
\hline 14. & 6845 & Exon 7 & $\mathrm{G} \rightarrow \mathrm{A}$ & $\mathrm{Val} \rightarrow \mathrm{Iso}$ & (HUSAINI et al. 1999) \\
\hline 15. & 6958 & Exon 7 & $A \rightarrow C$ & Leu $\rightarrow$ Pro & (HUSAINI et al. 1999) \\
\hline
\end{tabular}

* Nucleotide position of mutation according to complete BTN gene sequence (GenBank Acc. No Z93 323)

\section{Material and methods}

The study involved 171 Jersey cows from the Siedlec herd (Central region of Poland) derived from 101 sires and 160 dams. The biological material for the study was peripheral blood, taken from external jugular vein and stored in test tubes containing anticoagulant $\left(\mathrm{K}_{3} \mathrm{EDTA}\right.$ ). DNA isolation was conducted using MasterPure ${ }^{\mathrm{TM}}$ DNA Purification Kit (EPICENTRE ${ }^{\circledR}$ Biotechnologies). Genotypes of animals were determined using PCR-RFLP method.

The PCR reaction was performed in GeneAmp 2400 (Perkin Elmer) thermocycler. The reaction mixture $(20 \mu \mathrm{l})$ contained: polymerase buffer, nucleotide $\operatorname{mix}(0.2 \mathrm{mM}), \mathrm{MgCl}_{2}$ $(2.5 \mathrm{mM}), \mathrm{F}$ and $\mathrm{R}$ primers $(1 \mu \mathrm{M}), \sim 60 \mathrm{ng}$ of genomic DNA, Taq polymerase ( 0.5 unit) (Fermentas) and deionized water (up to $20 \mu \mathrm{l}$ ). The following temperature profile was used: initial denaturation of templates for $5 \mathrm{~min}$ at a temperature of $94^{\circ} \mathrm{C}$, the next 35 cycles were repeated; denaturation at $94^{\circ} \mathrm{C} / 60 \mathrm{~s}$, annealing at $64^{\circ} \mathrm{C} / 60 \mathrm{~s}$, extension at $72^{\circ} \mathrm{C} / 90 \mathrm{~s}$ and in the end, a final PCR product extension at a temperature of $72^{\circ} \mathrm{C}$ for 5 min.

In the amplification reaction, primers proposed by Komisarek and Dorynek (KOMISAREK and DORYNEK 2002) were used, with the modification of reverse (R) primer, which allowed for simultaneous detection of two polymorphic sites:

$\begin{array}{ll}\text { F: } & \text { 5'-TGG AGC TCT ATG GAA ATG GG-3' } \\ \text { R: } & \text { 5'-GGA ATA GGC CCT TCC TAA TC-3' }\end{array}$ 
A 568 bp fragment of BTN gene was amplified. Polymorphic sites were identified using restriction enzymes; the $A \rightarrow G$ substitution in position 6804 using Haell enzyme (KOMISAREK and DORYNEK 2002), and the substitution $G \rightarrow A$ in position 6845 using Schl enzyme. The restriction pattern for Schl enzyme was determined using NEBcutter (VINCZE et al. 2003). For both enzymes (Fermentas), the digestion was conducted at $37^{\circ} \mathrm{C}$ (minimum 3 h or overnight) using 4 units of each restriction enzyme. Restriction fragments were separated in agarose gels; in the case of Haell digestion separation was conducted in $2 \%$ gel (BASICA GQT, Prona), at $120 \mathrm{~V}$, in $1 \mathrm{X}$ TBE buffer, and in the case of Schl digestion, $3 \%$ agarose gel was used (70V, 1X TBE). Gels were stained with ethidium bromide (1.0 $\mu \mathrm{M})$ (AppliChem), and the results were analysed in UV light (312 $\mathrm{nm})$.

Data on the milk performance of cows was obtained from the farm documentation. Analysis of the level of traits associated with milk performance (overall milk, protein and fat yields as well as fat and protein contents) was conducted according to polymorphic variants of butyrophilin gene using the linear model:

$$
Y_{i j k l}=\mu+G_{i}+s_{j}+d_{k}+L_{l}+a\left(x-x_{m}\right)+\beta\left(d m-d m_{m}\right)+e_{i j k l}
$$

where $Y_{i j k l}$ is the analysed trait, $\mu$ is the overall mean, $G_{i}$ is the fixed effect of the analysed genotypes from each polymorphism, $s_{j}$ is the random effect of a sire, $d_{k}$ is the random effect of a dam, $L$, is the fixed effect of the number of lactation, $a$ is the regression coefficient for the cow calving age, $x$ is the calving age of a cow, $x_{m}$ is the mean calving age of the analysed cows, $\beta$ is the regression coefficient for the number of days in milk, $d m$ is the days in milk of a cow, $d m_{m}$ is the mean number of days in milk of cows and $e_{i j k l}$ is the random error.

Analysis were conducted using Statistica ${ }^{\circledR} 8.0$ package.

\section{Results}

As a result of conducted PCR-RFLP analysis three genotypes were identified ( $A A, A G i G G)$ for both restriction enzymes (Haelll and Schl) Figure 2. The frequencies of allels and genotypes for the analysed population are shown in Table 2.

Table 2

Frequencies of allels and genotypes of BTN/Haelll and BTN/Schl in studied population of cows Allel- und Genotypfrequenzen BTN/Haelll i BTN/Schl in der untersuchten Population

\begin{tabular}{lccccc}
\hline Polymorphism & \multicolumn{3}{c}{ Genotypes } & \multicolumn{3}{c}{ Alleles } \\
\hline BTN/HaellI & $A A$ & $A G$ & $G G$ & $A$ & $G$ \\
& 0.480 & 0.421 & 0.099 & 0.690 & 0.310 \\
& $(\mathrm{n}=82)$ & $(\mathrm{n}=72)$ & $(\mathrm{n}=17)$ & & \\
BTN/Schl & $A A$ & $A G$ & $G G$ & $A$ & $G$ \\
& 0.205 & 0.357 & 0.438 & 0.383 & 0.617 \\
& $(\mathrm{n}=35)$ & $(\mathrm{n}=61)$ & $(\mathrm{n}=75)$ & & \\
\hline
\end{tabular}

The effect of each genotype (BTN/Haell and BTN/Schl) on milk production traits was analysed in this study. The results are presented in Table 3. 
Owing to a lack of full linkage between the studied polymorphic sites, except for isolated genotypes, the influence of the combined genotypes (BTN/HaellI/Schl) on the examined phenotype traits was also analysed (Table 4).

Table 3

Means and standard deviations (SD) of milk production traits in Jersey cows carrying different BTN genotypes Durchschnittliche Standardabweichungen von Milchproduktionsmerkmalen bei Jersey-Rindern in Abhängigkeit vom Genotyp

\begin{tabular}{ccccccccccc}
\hline Genotype & \multicolumn{2}{c}{ Milk, kg } & \multicolumn{2}{c}{ Fat, kg } & \multicolumn{2}{c}{ Fat, $\%$} & \multicolumn{2}{c}{ Protein, kg } & \multicolumn{2}{c}{ Protein, \% } \\
\hline BTN/HaellI & $\overline{\mathrm{x}}$ & $\mathrm{SD}$ & $\overline{\mathrm{x}}$ & $\mathrm{SD}$ & $\overline{\mathrm{x}}$ & $\mathrm{SD}$ & $\overline{\mathrm{x}}$ & $\mathrm{SD}$ & $\overline{\mathrm{x}}$ & SD \\
AA & $4508^{\mathrm{A}}$ & 816 & 252.27 & 47.96 & $5.62^{\mathrm{a}}$ & 0.55 & $174.84^{\mathrm{A}}$ & 31.64 & 3.88 & $0.24^{\mathrm{AG}}$ \\
& $4559^{\mathrm{B}}$ & 827 & 253.13 & 45.72 & 5.61 & 0.52 & 178.25 & 30.60 & 3.92 & 0.23 \\
GG & $4853^{\mathrm{AB}}$ & 789 & 265.93 & 48.42 & $5.47^{\mathrm{a}}$ & 0.36 & $186.35^{\mathrm{A}}$ & 31.10 & 3.84 & 0.22 \\
BTN/Schl & $\overline{\mathrm{x}}$ & $\mathrm{SD}$ & $\overline{\mathrm{x}}$ & $\mathrm{SD}$ & $\overline{\mathrm{x}}$ & $\mathrm{SD}$ & $\overline{\mathrm{x}}$ & $\mathrm{SD}$ & $\overline{\mathrm{x}}$ & $\mathrm{SD}$ \\
A $A$ & 4447 & 815 & 247.06 & 46.74 & $5.57^{\mathrm{a}}$ & 0.51 & 172.78 & 31.25 & 3.89 & 0.23 \\
AG & 4571 & 789 & 254.86 & 46.38 & $5.62^{\mathrm{a}}$ & 0.55 & 179.71 & 31.08 & 3.92 & 0.23 \\
GG & 4688 & 855 & 260.87 & 47.67 & 5.61 & 0.51 & 180.02 & 31.09 & 3.87 & 0.25 \\
\hline
\end{tabular}

Means in columns with the same letter differ significantly, capitals $P \leq 0.01$, small letters $P \leq 0.05$.

Table 4

Means and standard deviations (SD) of milk production traits in Jersey cows carrying different BTN combined genotypes

Durchschnittliche Standardabweichungen von Milchproduktionsmerkmalen bei Jersey-Rindern in Abhängigkeit von den kombinierten Genotypen

\begin{tabular}{lccccc}
\hline Combined genotype (Haelll/Schl) & Milk, kg & Protein, $\mathrm{kg}$ & Protein, $\%$ & Fat, $\mathrm{kg}$ & Fat, $\%$ \\
\hline$A A / A A$ & 4405 & 171.08 & 3.89 & 246.49 & $5.61^{\mathrm{B}}$ \\
$(\mathrm{n}=28)$ & $(859)$ & $(33.11)$ & $(0.22)$ & $(49.42)$ & $(0.52)$ \\
$A A / A G$ & 4487 & 169.87 & $3.78^{\mathrm{ab}}$ & 242.80 & $5.44^{\text {adg }}$ \\
$(\mathrm{n}=5)$ & $(606)$ & $(25.81)$ & $(0.22)$ & $(43.10)$ & $(0.86)$ \\
$A A / G G$ & 4669 & 181.54 & 3.90 & 262.93 & $5.66^{\text {abcA }}$ \\
$(\mathrm{n}=49)$ & $(767)$ & $(29.58)$ & $(0.28)$ & $(45.23)$ & $(0.53)$ \\
$A G / A A$ & 4620 & 180.33 & $3.92^{\mathrm{b}}$ & 250.10 & $5.43^{\text {beh }}$ \\
$(\mathrm{n}=11)$ & $(680)$ & $(24.10)$ & $(0.30)$ & $(38.00)$ & $(0.55)$ \\
$A G / A G$ & 4570 & 180.55 & $3.94^{\mathrm{a}}$ & 256.27 & $5.65^{\text {ghiD }}$ \\
$(\mathrm{n}=51)$ & $(808)$ & $(31.09)$ & $(0.22)$ & $(46.87)$ & $(0.51)$ \\
$A G / G G$ & 4458 & 166.07 & 3.83 & 240.93 & $5.57^{\mathrm{C}}$ \\
$(\mathrm{n}=10)$ & $(1015)$ & $(30.72)$ & $(0.19)$ & $(44.79)$ & $(0.55)$ \\
$G G / A A$ & 4530 & 175.23 & 3.87 & 247.08 & $5.44^{\text {cfi }}$ \\
$(\mathrm{n}=9)$ & $(587)$ & $(23.66)$ & $(0.23)$ & $(37.11)$ & $(0.35)$ \\
$G G / A G$ & 4891 & 189.50 & 3.84 & 254.75 & $5.21^{\text {defBCDE }}$ \\
$(\mathrm{n}=2)$ & $(895)$ & $(48.37)$ & $(0.30)$ & $(46.37)$ & $(0.07)$ \\
$G G / G G$ & 5030 & 192.09 & 3.82 & 278.52 & $5.54^{\mathrm{E}}$ \\
$(\mathrm{n}=6)$ & $(843)$ & $(31.31)$ & $(0.21)$ & $(52.08)$ & $(0.38)$ \\
\hline
\end{tabular}

Means in columns with the same letter differ significantly, capitals $P \leq 0.01$, small letters $P \leq 0.05$. 


\section{Discussion}

It is supposed that, in milk-fat secretion process, butyrophilin interacts with other proteins that are the part of milk-fat globule membranes (MFGM) i.a. with xanthin oxidase (XO) and adipophilin (ADPH) Figure 1 (MATHER and KEENAN 1998, McMANAMAN et al. 2007). Interaction of BTN and XO complex with adipophilin and probably other proteins present on the surface of intracellular lipid droplets could be involved in moving the lipid droplets closer to the apical part of cell membrane (HEID and KEENAN 2005).

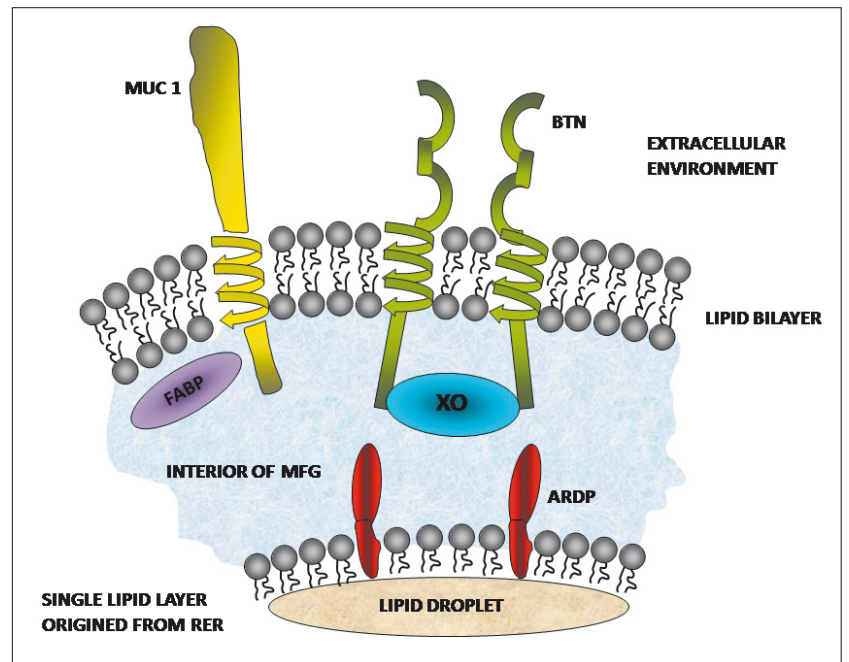

Figure 1

Putative arrangement of selected proteins present in the MFGM structure. MUC 1 mucin, $X O$ xantin oxidase, BTN butyrophilin, ADRP adipophilin, FABP fatty acids binding protein. (Prepared on the basis of: MATHER and JACK 1993, MATHER and KEENAN 1998, MCMANAMAN et al. 2007)

Mutmaßliche Anordnung von ausgewählten Proteinen in der MFGM-Struktur.

An importance of butyrophilin in milk-fat secretion process was confirmed by experiments carried out on Btn gene knock-out mice (Btn-/-), in which lipids were accumulated in mammary epithelial cells, but were not released at all from the cell (OGG et al. 2004). Interesting results have been presented in studies of the structure of milk-fat globule membranes, conducted using freeze-fracture technique, which point at dominant function of butyrophilin in controlling the process of milk-fat secretion (ROBENEK et al. 2006).

When analysing the obtained frequencies of genotypes, in the case of BTN/Haell polymorphism, considerably higher frequency of GG genotype was observed among Jersey cows compared to the Holstein-Friesian cows, in which GG genotype occurred very rarely (unpublished results) or was completely absent (HUSAINI et al. 1999, KOMISAREK and DORYNEK 2002). The obtained values are similar to the values obtained previously by other authors (KOMISAREK et al. 2006b). In the case of the second polymorphic site (BTN/ $S c h l)$, the frequencies of individual genotypes and allels were similar to those for BTN/Haelll polymorphism, however, incomplete linkage between the studied sites was observed, despite relatively small distance between them. It is also worth mentioning that homozygotic genotype $B T N / S c h{ }^{A A}$ was observed in twice as many individuals $(n=35)$ as the parallel genotype $B T N /$ HaellI ${ }^{G G}(\mathrm{n}=17)$.

The results of conducted analysis also showed the existence of statistically significant differences in the level of production traits depending on genotype. The highest yield of milk was observed in the cows with BTN/Haell ${ }^{G G}$ genotype $(P \leq 0.01)$, but unfortunately, among 
animals with that genotype, lower percentage fat content in milk $(P \leq 0.05)$ was simultaneously observed in comparision with individuals with BTN/HaellI ${ }^{A A}$ genotype. Nevertheless, cows with $B T N / H a e l \|{ }^{G G}$ genotype were characterized by over $11 \mathrm{~kg}$ higher fat yield than individuals with $B T N /$ HaellIAA genotype $(P \leq 0.01)$.
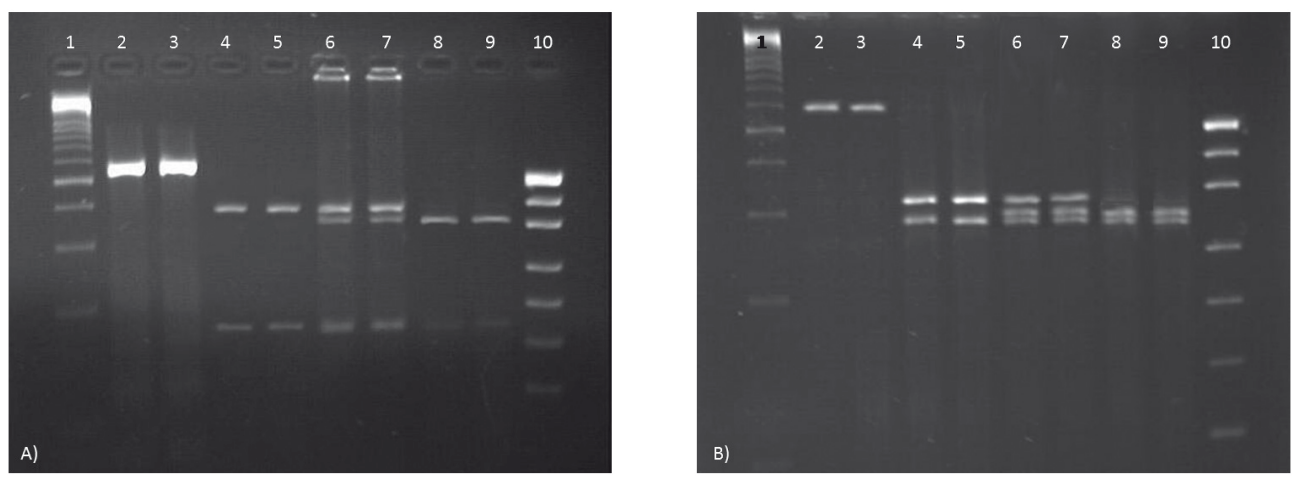

Figure 2

Results of PCR-RFLP analysis

A) BTN/HaellI: 1 = mass marker DNA GenRuler DNA Ladder Mix (Fermentas), 2, 3 = PCR product (568 bp) 4 , $5=$ AA genotype (371 and 162 bp), 6, $7=$ AG genotype (371, 338 and 162 bp), 8, $9=$ GG genotype (338 and 162 bp), 10 = mass marker pUC19/Mspl 23 (Fermentas). Restriction fragments 10, 12, 13 and 33 bp long were invisible on gel.

B) BTN/Schl: 1 = mass marker DNA GenRuler DNA Ladder Mix (Fermentas), 2, $3=$ PCR product (568 bp); 4 , 5 = AA genotype (315 and 253 bp), 6, 7 = AG genotype (315, 264 and 253 bp); 8, 9 = genotyp GG genotype (264 and 253 bp), 10 = mass marker PUC19/Mspl 23 (Fermentas). Fragment 51 bp long was invisible in the photograph.

Ergebnisse der PCR-RFLP-Analyse

The analysis of investigated milk performance traits in a configuration of combined genotypes showed the existence of influence of this genotypes on percentage fat contents in milk. The highest fat content ( $5.66 \%$ and $5.65 \%$ ) was observed among individuals possessing the most frequently occuring combination of genotypes of $B T N$ gene respectively $(A G / A G, \mathrm{n}=51$ and $A A / G G, \mathrm{n}=49$ ). The $G G / A G$ combination of genotypes deserves special attention, because it seems to negatively influence fat content in milk (5.21\%). However, in the analysed population, only two individuals were carrying this genotypes combination. Simultaneous analysis of the two BTN genotypes seems to be appropriate, because those genotypes are not isotaled from each other and, in nature, function together within one organism.

Information stored in DNA determines the primary structure of protein. Other levels of protein organization depend largely on the amino acids sequence in the polypeptide chain. Point mutations located in exons may, although not always, result in changes in the primary structure of protein. Butyrophilin protein is composed of three functional domains. On the side of the cytoplasm, just behind the transmembrane region, at the C-terminus of polypeptide chain, a highly conservative domain, known as B30.2, is located. This region represents almost $70 \%$ of cytoplasmatic domain sequence (MATHER 2000).

Nucleotide substitutions investigated in this study (6804 and 6845) are both located in the region of the gene coding B30.2 domain of butyrophilin protein. What is important, the 
individual mutations affect the formation of protein with different amino acid composition. In the case of substitution detected using Haell enzyme, lysine is converted to arginine, whereas the nucleotide substitution in polymorphic site recognized by Schl enzyme changes the valine to isoleucine (Table 1). In both cases, there is a conversion to the amino acid with similar properties (BETTS and RUSSEL 2003), so it can be assumed that this substitutions have no significant impact on the structure of proteins of higher order. Moreover, it has been shown that these amino acids are the most frequently mutually substituted in proteins found in cell membranes (BETTS and RUSSEL 2003).

It is not known exactly whether the amino acids are in places directly involved in the ligand binding, hence the need to create a spatial model of protein, useful in clarifying the impact of observed changes in the spatial conformation of endoplasmatic domain. Such a model could also be helpful in recognition and explanation of the molecular mechanism of binding the B30.2 domain with ligand, showing any differences between variants of butyrophilin and the efficiency of their ligand binding, and consequently varied releasing of lipid droplets outside the cell. In the case of mutation, the fat would be released into milk less intensively, which would explain the results received in this work.

The observed lack of linkage between different polymorphic sites is also worth mentioning. The distance between polymorphic sites is only 41 nucleotides, but particular alleles occur with different frequency (Table 1). Because of such small distance, crossing-over between analysed places should not occur too often. This leads to the emergence of a different amino acid composition within the B30.2 domain. This seems interesting, given the fact that this domain is considered to be evolutionally conservative, hence the changes within it should not take place. Evolutionary mechanisms only preserve these changes, which give some new beneficial properties to proteins. It is possible that, in the case of butyrophilin, these changes have beneficial impact on the functions of protein.

Complexity of the butyrophilin structure, its not fully understood function, and interesting properties, make the protein a very interesting object of research. In addition, there is still a lot of details to describe concerning its structure and the molecular mechanisms affecting the interaction with other elements responsible for the milk-fat secretion. In conclusion, the obtained results, despite receiving some statistically significant differences, do not appear to be sufficient to render the BTN gene variants as useful markers for the selection of dairy cattle, probably because this gene is linked with QTL located in close neighborhood (KOMISAREK and DORYNEK 2002). In addition, because of a low number of individuals in some genotype groups, obtained results need further verification.

\section{References}

Ashwell MS, van Tassell CP (1999) Detection of putative loci affecting milk, health and type traits in a US holstein population using 70 microsatellite markers in a genome scan. J Dairy Sci 82, 2497-2502

Banghart LR, Chamberlain CW, Verlade J, Korobko IV, Ogg SL, Jack LJW, Vakharie VN, Mather IH (1998) Butyrophilin is expressed in mammary epithelial cells from a single - sized messenger RNA as a type I membrane glycoprotein. J Biol Chem 273, 4171-9

Betts MJ, Russell RB (2003) Amino acid properties and consequences of substitutions. Bioinformatics for Geneticists, in: Barnes MR, Gray IC, editor. Bioinformatics for Geneticists. Wiley, 289-316

Brunner RM, Guerin G, Goldammer T, Seyfert HM, Schwerin M (1996) The bovine butyrophilin encoding gene (BTN) maps to chromosome 23. Mammalian Genome 7, 635-6 
Davey HW, Ogg SL, Husaini Y, Snell RG, Korobko IV, Mather IH, Wilkins RJ (1997) Structure and sequence of the bovine butyrophilin gene. Gene 199, 57-62

Franke WW, Heid HW, Grund C, Winter S, Freundenstein C, Schmid E, Jarasch ED, Keenan TW (1981) Antibodies to the major insoluble milk fat globule membrane - associated protein: specific location in apical regions of lactating epithelial cells. J Cell Biology 89, 485-94

Heid HW, Keenan TW (2005) Intracellular origin and secretion of milk fat globules. European J Cell Biology 84, 245-58

Husaini Y, Wilkins RJ, Davey HW (1999) Identification of five point mutations, including an Alul RFLP, in the bovine butyrophilin gene. Anim Genet 30, 382-405

Jack LJW, Mather IH (1990) Cloning and analysis of CDNA encoding bovine butyrophilin, an apical glycoprotein expressed in mammary tissue and secreted in association with the milk - fat globule membrane during lactation. J Biol Chem 265, 14481-6

Komisarek J, Dorynek Z (2002) Polymorphism analysis of BTN, GHR, and CYP19 genes in cattle. Zeszyty Naukowe Przeglądu Hodowlanego 62, 295-302 [in Polish]

Komisarek J, Antkowiak I, Pytlewski J, Dorynek Z, Waśkowicz K (2006a) Effect of polymorphism in gene BTN1A1 on somatic cell count in milk of Jersey cows. Polish J Food and Nutrition Sci 15/16 SI 1, 101-5

Komisarek J, Waśkowicz K, Dorynek Z (2006b) Analysis of the relationship between two single nucleotide polymorphisms of the butyrophilin (BTN1A1) gene and milk production traits in Jersey cattle. Ann Anim Sci $6,45-52$

Mather IH, Jack LJW (1993) A review of the molecular and cellular biology of butyrophilin, the major protein of bovine milk fat globule membrane. J Dairy Sci 76, 3832-50

Mather IH, Keenan TW (1998) Origin and secretion of milk lipids. J Mammary Gland Biol Neoplasia 3, 259-73

Mather IH (2000) A review and proposed nomenclature for major proteins of the milk - fat globule membrane. J Dairy Sci 83, 203-47

McManaman JL, Russel TD, Schaack J, Orlicky DJ, Robenek H (2007) Molecular determinants of milk lipid secretion. J Mammary Gland Biol Neoplasia 12, 259-68

Ogg LS, Weldon AK, Dobbie L, Smith AJ, Mather IH (2004) Expression of butyrophilin (Btn1a1) in lactating mammary gland is essential for the regulated secretion of milk - lipid droplets. Proc Natl Acad Sci USA 101, 10084-9

Robenek H, Hofnagel O, Buers I, Lorkowski S, Schnoor M, Robenek MJ, Heid H, Troyer D, Severs NJ (2006) Butyrophilin controls milk fat globule secretion. Proc Natl Acad Sci USA 103, 10385-90

Seyfert HM, Luthen F (1998) The structure of the bovine butyrophilin encoding gene differs grossly from mouse concerning promoter localization and exon organization of the $S$ - untranslated region. Proceedings of the 6th World Congress on Genetics Applied to Livestock Production 25, 51-4

Taylor C, Everest M, Smith C (1996) Restriction fragment length polymorphism in amplification products of the bovine butyrophilin gene: assignment of bovine butyrophilin to bovine chromosome 23. Anim Gen 27, 183-5

Vincze T, Posfai J, Roberts RJ (2003) NEBcutter: a program to cleave DNA with restriction enzymes. Nucleic Acids Res 31, 3688-91

Zegeye A, Ashwell M, Ogg S, Rexroad C, Mather IH (1999) RFLP markers in the bovine butyrophilin gene. Anim Genet 30, 382-405

Received 13 February 2009, accepted 22 July 2010.

Corresponding author:

MAGDALENA MUSZYŃSKA

email: magdalena.muszynska@zut.edu.pl

Laboratory of Molecular Cytogenetics, Department of Ruminant Sciences, Faculty of Biotechnology and Animal Breeding, West Pomeranian University of Technology, Doktora Judyma 10, 71-460 Szczecin, Poland 